\title{
Rancang Bangun Aplikasi Ensiklopedia Kesehatan Berbasis Android
}

\author{
Ferdiyani Haris \\ Program Studi Sistem Informasi - STMIK Palangkaraya \\ Jl. G.Obos No. 114 Palangkaraya, Kalimantan Tengah \\ E-mail : sabila006@gmail.com
}

\begin{abstract}
ABSTRAK
Dalam dunia kesehatan terdapat banyak istilah kesehatan yang sulit dipahami. Buku ensiklopedia kesehatan merupakan salah satu media yang menyajikan penjelasan tentang istilah-istilah tersebut. Namun dalam penggunaanya buku cetak tersebut kurang efektif dan efisien dikarenakan terbatas ruang dan waktu. Sehingga diperlukan sebuah media yang menyajikan penjelasan istilah kesehatan yang bersifat mobile agar dapat digunakan kapanpun dan dimanapun. Aplikasi ini dirancang dan diimplementasi untuk sistem operasi android. Sistem yang dibuat bertujuan untuk menampilkan definisi serta gambar dari istilah kesehatan. Metode penelitian yang digunakan adalah metode riset dan pengembangan. Sedangkan untuk pengembangan sistem perangkat lunak menggunakan model pengembangan perangkat lunak Systems Development Life Cycle (SDLC) waterfall.

Berdasarkan hasil respon terhadap pengguna aplikasi yang dilakukan dengan kuesioner menghasilkan nilai $88,9 \%$ menyatakan sangat baik.
\end{abstract}

Kata kunci : Ensiklopedia kesehatan, Android, Waterfall.

\section{ABSTRACT}

In the health world there are many elusive health terms. The encyclopedia of health is one of the media that provides an explanation of these terms. But in its use the printed book is less effective and efficient due to limited space and time. So it takes a media that presents an explanation of mobile health terms that can be used anytime and anywhere. This app is designed and implemented for android operating system. The system created aims to display the definition and image of the term health. The research method used is research and development method. As for the development of software systems using software development lifecycle development model Cycle (SDLC) waterfall. Based on the results of responses to users of applications conducted with questionnaires resulted in $88.9 \%$ stated very good value.

Keywords : Health encyclopedia, Android, Waterfall

\section{Pendahuluan}

Dalam dunia kesehatan ada banyak istilah dan memiliki keterkaitan satu dengan yang lain sehingga sulit untuk dipahami oleh kebanyakan orang. Istilah kesehatan tidak hanya mengenai nama penyakit, tetapi juga meliputi berbagai penyebab penyakit, komposisi obat-obatan, anatomi tubuh manusia (antropotomi) dan lain-lain yang dicetak berupa buku yaitu ensiklopedia kesehatan.

Buku cetak memiliki ketidakpraktisan dalam penggunaannya. Terutama buku yang terkait dengan ensiklopedia kesehatan memiliki ratusan bahkan ribuan halaman. Oleh karena itulah akan dibuat suatu aplikasi yang dapat mempermudah untuk mendapatkan serta memahami definisi dari istilah tersebut dengan memanfaatkan teknologi mobile yang berkembang pesat saat ini. Teknologi mobile tersebut akan menggunakan sistem operasi android yang bersifat open source.

\section{Tinjauan Pustaka}

2.1 Penelitian Ernilisa (2013) yang berjudul Implementasi Encyclopedia Komputer Berbasis Multimedia, menjelaskan tentang sebuah aplikasi encyclopedia yang menyajikan istilahistilah komputer sebagai sarana pembelajaran yang disertakan dengan gambar, suara dan video dari istilah tersebut dan aplikasi ini dibuat menggunakan pemrograman Visual Basic 6.0.

2.2 Penelitian Puji Rahayu, dkk (2014) yang berjudul Rancang Bangun Aplikasi Ensiklopedia Batik Indonesia Berbasis Android, 
menjelaskan tentang aplikasi ensiklopedia yang bersifat client-server. Server didesain menggunakan PHP dan MySQL serta Client diterapkan pada smartphone dan tablet android. Data yang diakses melalui perangkat android menggunakan JSON sebagai format pertukaran datanya.

2.3 Penelitian Deanesa Mharfhin, dkk (2012) yang berjudul Aplikasi Ensiklopedia Dinamis Tanaman Herbal Berbasis Android. Mendesain sebuah aplikasi ensiklopedia tanaman herbal yang bersifat dinamis pada web dan android. Para pengguna dapat melakukan registrasi untuk menjadi anggota (member) agar dapat menambah ataupun meng-edit data pada database aplikasi.

\section{Metode Penelitian}

Penelitian ini menggunakan model pengembangan perangkat lunak Waterfall yang terdiri dari analisa, perancangan, implementasi dan pengujian.

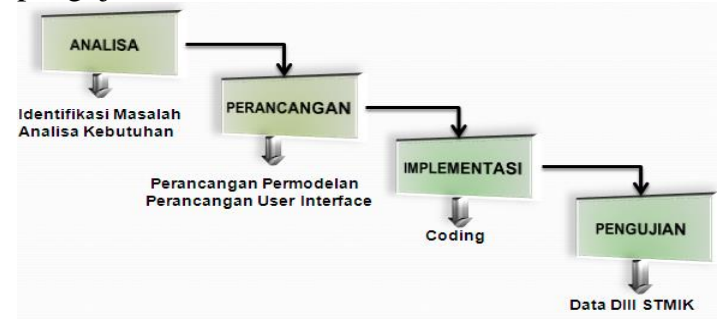

Gambar 2. Pengembangan perangkat lunak model Waterfall

\section{Desain Sistem}

4.1 Desain proses

4.1.1 Use case diagram

Berikut adalah desain Use case diagram :

Gambar 3. Use case diagram

\subsubsection{Activity diagram}

Gambar berikut adalah desain activity diagram definisi istilah dan update :

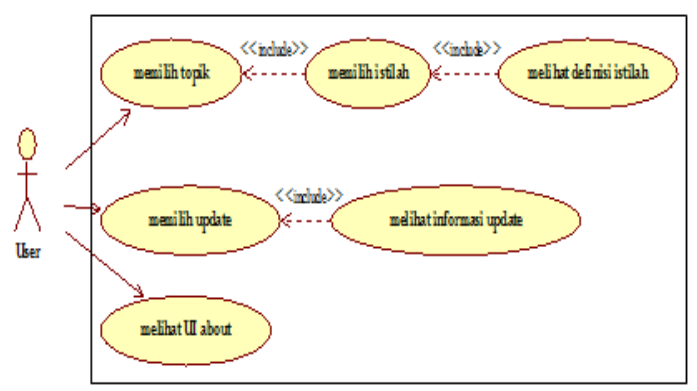

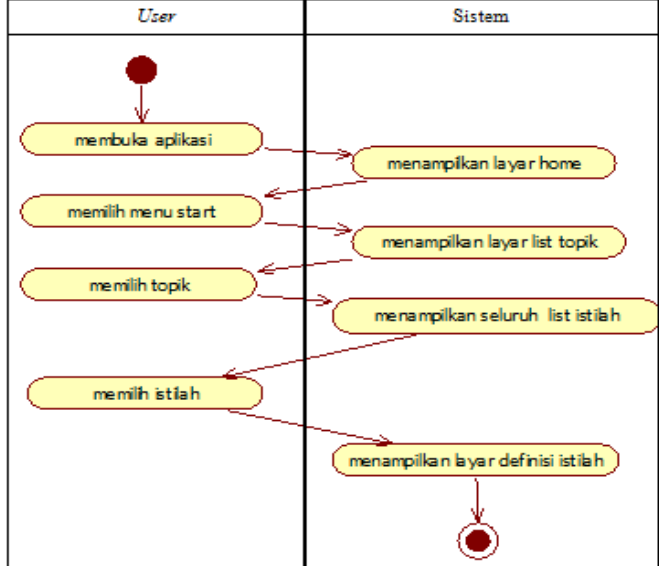

Gambar 4. Activity diagram definisi istilah

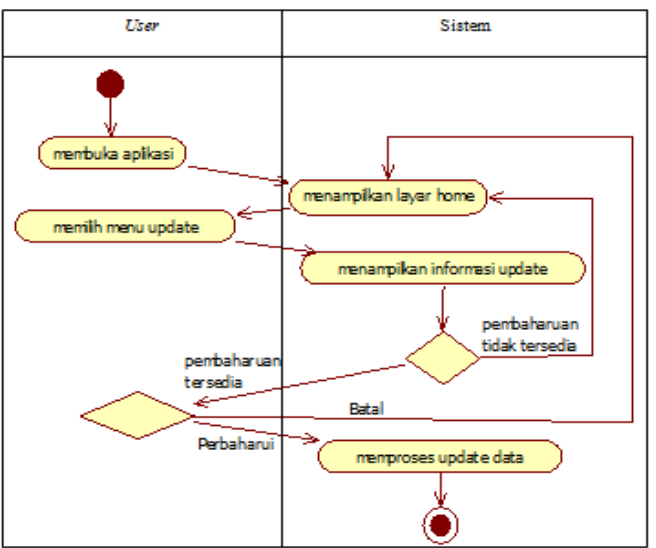

Gambar 6. Activity diagram update

\subsubsection{Sequence diagram}

Gambar 7 dan 8 menunjukkan sequence diagram UI definisi istilah dan update :

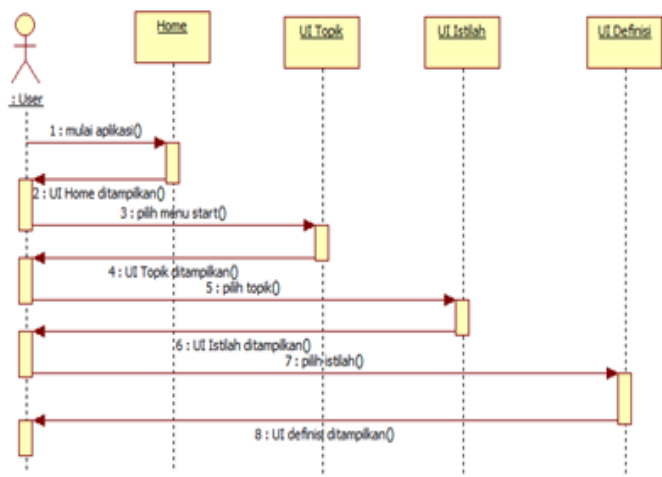

Gambar 7. Sequence diagram UI definisi istilah 


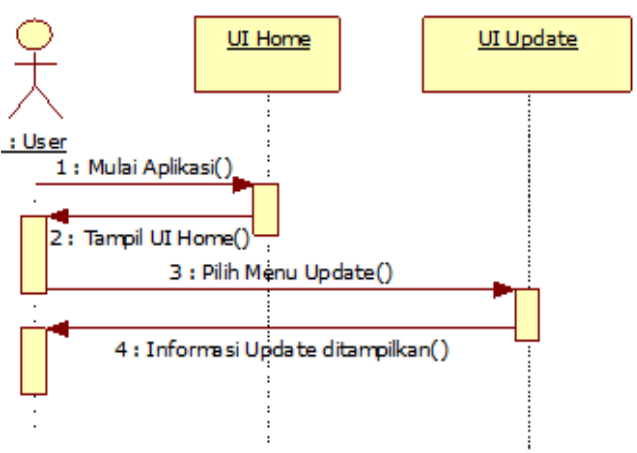

Gambar 8. Sequence diagram UI update

\subsubsection{Statechart diagram}

Statechart diagram aplikasi dapat dilihat pada gambar berikut :

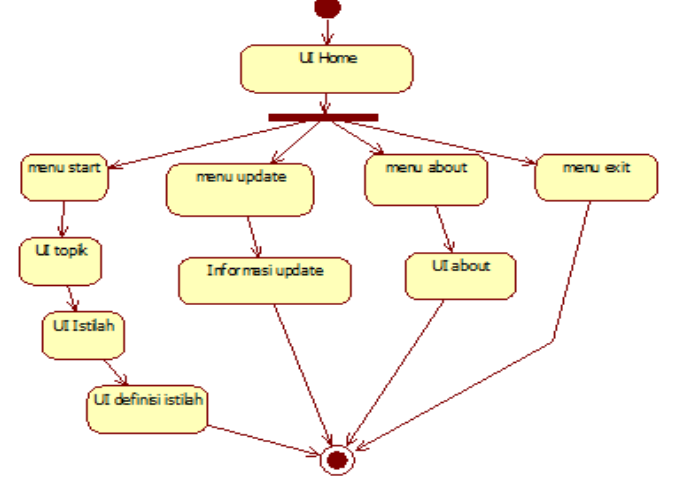

Gambar 9. Statechart diagram aplikasi

\subsubsection{Class diagram}

Berikut adalah gambar Class diagram :

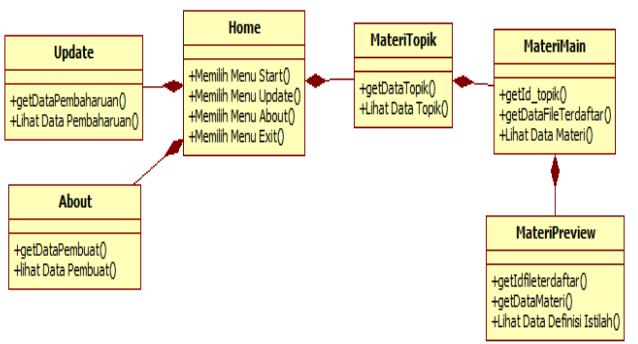

Gambar 10. Class diagram

\subsection{Desain Entity Relationship Diagram (ERD)}

Gambar berikut menunjukkan desain Entity Relationship Diagram (ERD) yang merupakan suatu model untuk menjelaskan hubungan antar data pada database.

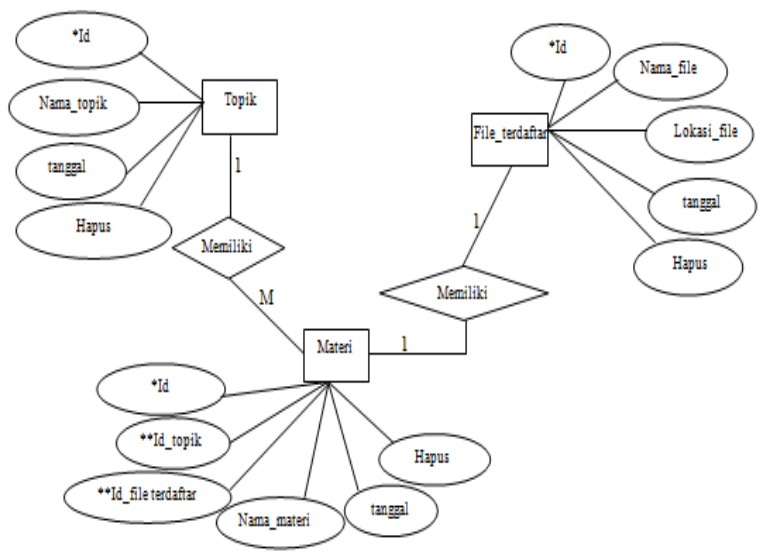

Gambar 11. Entity Relationship diagram (ERD)

\section{Pembahasan dan Pengujian \\ 5.1. Pembahasan}

Tahap ini merupakan tahap yang berisi penjelasan tentang manual antar muka sistem. Antar muka pengguna pada sistem ini terdiri dari antar muka home yang merupakan menu utama aplikasi, antar muka Topik terdiri dari beberapa pilihan topik kesehatan, antar muka istilah yang terdiri dari beberapa pilihan istilah pada setiap topik kesehatan yang dipilih, antar muka definisi istilah akan tampil setelah user, antar muka Update UI update adalah infomasi pemberitahuan kepada user tentang ketersediaan pembaharuan yang dapat dipilih untuk memperbaharui data ataupun tidak.

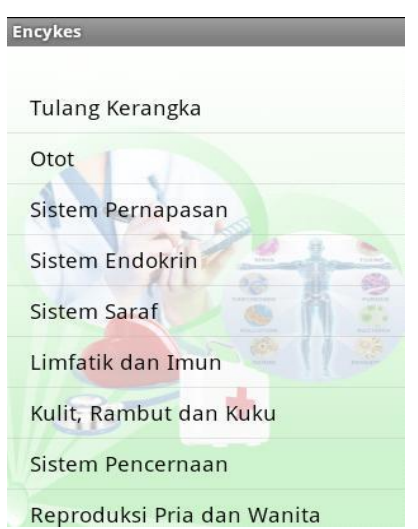

Gambar 12. Antar muka Topik 


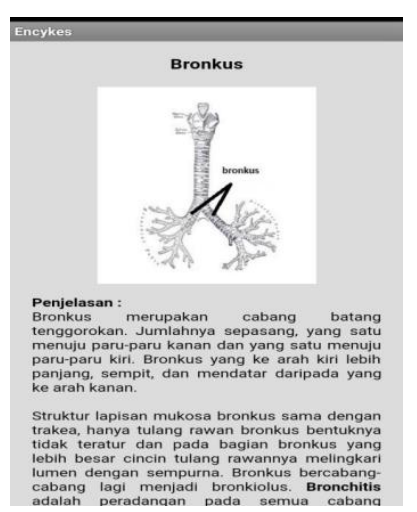

Gambar 13. Antar muka definisi istilah

\subsection{Pengujian Sistem}

Pengujian sistem yang telah dibangun dilakukan dengan membagi kuesioner yang berisi 5 pernyataan kepada 25 responden secara acak. Hasil pengujian sistem menghasilkan nilai $88,9 \%$ menyatakan sangat baik.

\section{Tabel 1.Hasil Kuesioner}

\begin{tabular}{|c|c|c|}
\hline No & Pernyataan & $\begin{array}{l}\text { Jumlah } \\
\text { Skor }\end{array}$ \\
\hline 1 & $\begin{array}{l}\text { Aplikasi ini menarik untuk } \\
\text { digunakan. }\end{array}$ & $95,2 \%$ \\
\hline 2 & $\begin{array}{l}\text { Aplikasi memiliki tampilan } \\
\text { yang } \\
\text { menarik. }\end{array}$ & $88 \%$ \\
\hline 3 & $\begin{array}{l}\text { Fungsi menu pada aplikasi } \\
\text { mudah dimengerti. }\end{array}$ & $85,6 \%$ \\
\hline 4 & $\begin{array}{l}\text { Aplikasi memudahkan } \\
\text { pengguna } \\
\text { untuk mendapatkan definisi } \\
\text { istilah kesehatan. }\end{array}$ & $87,2 \%$ \\
\hline 5 & $\begin{array}{l}\text { Materi yang disampaikan } \\
\text { mudah } \\
\text { dimengerti. }\end{array}$ & $88,8 \%$ \\
\hline & JUMLAH SKOR AKHIR & $88,9 \%$ \\
\hline
\end{tabular}

\section{Kesimpulan}

6.1 Telah dibangun sebuah Aplikasi Ensiklopedia Kesehatan Berbasis Android menggunakan bahasa pemrograman java, dengan menggunakan fungsi webview untuk menampilkan definisi istilah serta menggunakan teknologi web service untuk pertukaran data
6.2 Berdasarkan hasil kuesioner sejumlah $88,9 \%$, aplikasi ini sudah memenuhi kebutuhan fungsional dan kebutuhan pengguna. Aplikasi ini juga dapat membantu user untuk mengetahui definisi dari istilah-istilah kesehatan

\section{Acuan Referensi}

Ernilisa. 2013. Implementasi Encyclopedia Komputer Berbasis Multimedia. STMIK Palangkaraya. Palangka Raya

Rahayu, Puji dan Erli Puspita Sari. 2014. Rancang Bangun Aplikasi Ensiklopedia Batik Indonesia Berbasis Android. STMIK GI MDP. Palembang.

Mharfhin, Deanesa, Yuli Fitrisia dan Sugeng Purwanto. 2012. Aplikasi Ensiklopedia Dinamis Tanaman Herbal Berbasis Android. Journal of :e-Journal Sistem Informasi, PCR.Vol 1.54.2012. Politeknik Caltex Riau. Pekanbaru.

\section{Daftar Pustaka}

Akmal, Mutaroh, dkk. 2016. Ensiklopedi Kesehatan Untuk Umum, Ar-Ruzz Media. Yogyakarta

Djuanda, Adhi, Mochtar Hamzah dan Siti Aisah (Ed.). 2002. Ilmu Penyakit Kulit dan Kelamin, Balai Penerbit FKUI. Jakarta

Ekadesy, Diana (Ed.). 2011. Ensiklopedia Kesehatan Wanita, Erlangga. Jakarta

Guritno, Suryo, Sudaryono, Untung Rahardja. 2011. Theory and Application of IT Research, Andi Offset, Yogyakarta.

Huda, Arif Akbarul. 2012. 24 Jam!! Pintar Pemrograman Android, Andi Offset, Yogyakarta.

Huda, Arif Akbarul. 2013. Live Coding! 9 Aplikasi Android Buatan Sendiri, Andi Offset, Yogyakarta.

Nugroho, Adi. 2010. Rekayasa Perangkat Lunak Berorientasi Objek dengan Metode USDP (Unified Software Development Process), Andi Offset, Yogyakarta.

Pressman, Roger S. 2012. Rekayasa Perangkat Lunak, Andi, Yogyakarta.

Wahana Komputer. 2013. Step by Step Menjadi Programmer Android. Yogyakarta

Winardini (Ed.). 2009. Ensiklopedia Tubuh Manusia, Erlangga. Jakart 